\title{
Aspirin and statin therapy in sepsis, a red herring?
}

\author{
R Campbell, A McGuire, L Young, A Mackay \\ From ESICM LIVES 2015 \\ Berlin, Germany. 3-7 October 2015
}

\section{Intr}

Severe sepsis is attributable to 37000 deaths per year in the United Kingdom [1]. Recent studies have suggested aspirin or statins have a beneficial effect in the treatment of sepsis, reducing overall mortality [2-4]. This is thought to be secondary to their anti-inflammatory effect, blocking inflammatory cascades triggered in sepsis $[2,3]$.

\section{Objectives}

To identify whether aspirin therapy, statin therapy or combination therapy improves survival in septic patients admitted to ICU compared to patients receiving neither.

\section{Methods}

Patients admitted with sepsis to a 5 bedded teaching hospital intensive care unit over a 2 year period from January 2013 to March 2015 were identified utilising the WardWatcher ${ }^{\mathrm{TM}}$ database. Demographic data, outcome data and medications prescribed during this time were obtained via the ICU clinical information system, specifically looking for aspirin and statin therapy prior to admission. This information was subsequently analysed using an Excel $^{\mathrm{TM}}$ spreadsheet.

\section{Results}

During the study period, there were a total of 218 (35.7\%) admissions to ICU identified with sepsis out of a total of 611 admissions. Ten were excluded due to incomplete data. Septic patients were split into four groups; aspirin therapy, dual aspirin and statin therapy, statin therapy, neither aspirin nor statin therapy.

The majority (61\%) of patients admitted with sepsis were on neither aspirin nor statin therapy. This patient group also had the lowest median age of 56. Median APACHE-II scores were similar in each group and this was reflected in the lack of any significant survival difference between groups. Patients on neither therapy were more likely to survive hospital admission (67.7\%)
Table 1 Medications prescribed

\begin{tabular}{lllll}
\hline & $\begin{array}{l}\text { Aspirin } \\
\text { therapy }\end{array}$ & $\begin{array}{l}\text { Statin } \\
\text { therapy }\end{array}$ & $\begin{array}{l}\text { Dual } \\
\text { therapy }\end{array}$ & $\begin{array}{l}\text { Neither } \\
\text { therapy }\end{array}$ \\
\hline Total number & 12 & 36 & 33 & 127 \\
\hline Male:Female ratio & $1: 1$ & $1: 1.25$ & $1: 1.2$ & $1: 1.1$ \\
\hline Median age (IQR) & $\begin{array}{l}70.5[61.25- \\
78.25]\end{array}$ & $\begin{array}{l}66[52.25- \\
75]\end{array}$ & $72[63-77]$ & $56[47-68.5]$ \\
\hline Surgical:Medical & $1: 3$ & $1: 2$ & $1: 0.7$ & $1: 0.69$ \\
\hline $\begin{array}{l}\text { Median APACHE- } \\
\text { II (IQR) }\end{array}$ & $\begin{array}{l}17.5[15.5- \\
\text { 24.5] }\end{array}$ & $20[17-28]$ & $20[16-26]$ & $20[14-27]$ \\
$\begin{array}{l}\text { \% Hospital } \\
\text { survival }\end{array}$ & 66.7 & 63.9 & 57.6 & 67.7 \\
\hline
\end{tabular}

than those on dual (57.6\%) or single aspirin or statin therapy, although this was not statistically significant.

\section{Conclusions}

Our study demonstrates no significant benefit in outcome from sepsis in intensive care with aspirin or statin therapy.

\section{Published: 1 October 2015}

\section{References}

1. Daniels R, Nutbeam T, McNamara G, Galvin C: The sepsis six and the severe sepsis resucitation bundle: a prospective observational cohort study. Emergency Medicine Journal 2011, 28(6):507-12.

2. O'Neal HR, Koyama T, Koehler EA, Siew E, Curtis BR, Fremont RD, May AK, Bernard GR, Ware LB: Prehospital statin and aspirin use in the prevalence of severe sepsis and acute lung injury/acute respiratory distress syndrome. Critical Care Medicine 2011, 39(6):1343-50.

3. Christensen $S$, Thomsen RW, Johansen MB, Pedersen $L$, Jensen $R$, Larsen KM, Larsson A, Tonnesen E, Sorensen HT: Preadmission statin use and one-year mortality among patients in intensive care - a cohort study. Critical Care 2010, 14(2):R29.

4. Dobesh PP, Klepser DG, McGuire TR, Morgan CW, Olsen KM: Reduction in mortality associated with statin therapy in patients with severe sepsis. Pharmacotheapy 2009, 29(6):621-30.

doi:10.1186/2197-425X-3-S1-A227

Cite this article as: Campbell et al:: Aspirin and statin therapy in sepsis, a red herring? Intensive Care Medicine Experimental 2015 3(Suppl 1):A227. 